\title{
WHO ARE YOU, MARIA DEAR? RECEPÇÃO DE UMA PROPOSTA DE TRADUÇÃO DE “AS MENINAS”, DE CECÍLIA MEIRELES, ENTRE CRIANÇAS NA INGLATERRA
}

\author{
WHO ARE YOU, MARIA DEAR? THE RECEPTION OF "GIRLS AT THE \\ WINDOW”, A TRANSLATION OF “AS MENINAS” (CECÍLIA MEIRELES) BY \\ CHILDREN IN ENGLAND
}

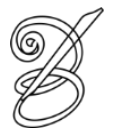 \\ Telma Franco DINIZ* \\ Universidade de São Paulo, Brasil
}

\begin{abstract}
Resumo: Em se tratando de poesia, tradutores idealmente procuram recriar, no poema de chegada, correspondentes para todos os atributos poéticos (métrico, fônico, prosódico, semântico) identificados no poema de partida. Na prática, entretanto, somos levados a escolher quais desses atributos priorizar, uma vez que, em tradução de poesia, é raramente possível obter correspondência em todos os níveis, sem nenhuma perda (BRITTO, 2002). Não raro nos perguntamos em que medida as alterações, cortes ou acréscimos, feitos em nome da métrica ou da rima, por exemplo, interferem na interpretação do poema traduzido. Nas traduções para o público infantil, há um complicador que intensifica a dúvida: a relação assimétrica entre as crianças leitoras e os adultos que escrevem ou traduzem para elas (AZENHA, 2008). Para reduzir essa assimetria e garantir a aceitação da obra junto ao público, é recomendável que os tradutores procurem se aproximar da linguagem do tempo para o qual traduzem (AZENHA, 2005), além de terem algum contato com crianças da idade daquelas para quem traduzem (LATHEY, 2016). Em que pesem as recomendações de Azenha e Lathey, e os avanços nos estudos sobre tradução de literatura infantil feitos nos últimos trinta anos, ainda são poucos os estudos que levam em conta a resposta do público leitor. Neste artigo, pretendo dar minha contribuição para reduzir essa lacuna: primeiro apresento minha proposta de tradução do poema "As meninas", de Cecília Meireles, e em seguida os dados de duas vivências com grupos de crianças estrangeiras de 9 e 10 anos de idade, que leram e discutiram o poema traduzido, intitulado "Girls at the window". As vivências foram realizadas em duas escolas da Inglaterra, de acordo com a prática de letramento Pensar Alto em Grupo (ZANOTTO, 2014), também brevemente explicada neste artigo.
\end{abstract}

Palavras-chave: Estudos da Tradução. Tradução de Literatura Infantil. Pensar Alto em Grupo. Cecília Meireles. Poesia para crianças.

\begin{abstract}
Translators of poetry ideally seek to re-create, in the target poem, the same poetic features seen in the source poem (metric, phonetic, prosodic, and semantic features). But in practice, we have to choose which features will take priority, since in poetry translation it is rarely possible to obtain correspondence on all levels, with no loss (BRITTO, 2002). We often wonder to what extent the changes, cuts or additions made regarding form (meter or rhymes, for instance) will interfere in the interpretation of the target poem. Concerning poetry for children, there is an extra challenge that adds to our wonder: the asymmetrical relationship between the child reader and the adult who writes or translates to the child (AZENHA, 2008). To reduce asymmetry and to improve the chances of the work being accepted by the target audience, translators should be very attentive of the language in use at the time of the translation (AZENHA, 2005), and try to spend some time with same-age children to whom they translate it (LATHEY, 2016). Despite Azenha's and Lathey's recommendations, and despite the growing number of research on translation of children's literature in the past thirty years, there are only a handful of studies that take the children's response into account. With this article I intend to contribute to reducing that gap: first, I present my translation into English of the poem "As meninas", originally written in Portuguese by Cecília Meireles, and then submit the results of two sessions of poetry-reading-and-discussion carried out with two different groups of 9 to 10 year-old English-speaking children, who read and discussed the translated poem entitled "Girls at the window". The sessions were held at two different schools in England, following the guidelines
\end{abstract}


of the dialogical and collaborative literacy practice Think Aloud in Group (ZANOTTO, 2014), to which I also provide a short explanation.

Keywords: Translation Studies. Translation of Children's Literature. Think Aloud in Group. Cecília Meireles. Poetry for children.

RECEBIDO EM: 13 de março de 2019

ACEITO EM: 04 de maio de 2019

PUBLICADO EM: julho 2019

\section{Introdução}

Se em tal assunto pudesse a autora exprimir alguma aspiração, talvez fosse a da organização de uma Biblioteca Infantil que aparelhasse a infância de todos os países para uma unificação de cultura, nas bases do que se poderia muito marginalmente chamar de "humanismo infantil". Na esperança de que, se todas as crianças se entendessem, talvez os homens não se hostilizassem.

(Cecília Meireles, 1984)

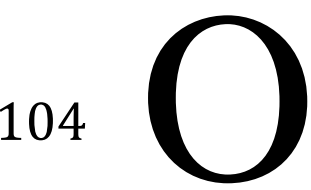

parágrafo em epígrafe, em que Cecília Meireles (1901-1964) expressa sua aspiração a um mundo melhor em que a literatura infantil seria uma das bases do que ela chamava de "humanismo infantil", foi publicado no livro Problemas da literatura

infantil, fruto de uma série de conferências ministradas por ela para educadores mineiros em Belo Horizonte, em janeiro de 1949. Era o pós-guerra, e homens e mulheres, perplexos com a descoberta dos campos de extermínio e demais inomináveis atrocidades cometidas durante a Segunda Guerra, perdiam a crença na humanidade. Porém, se o mundo adulto estava desolado e corrompido, ainda se podia apostar nas crianças. A ideia de que "se todas as crianças se entendessem, talvez os homens não se hostilizassem" (MEIRELES, 1984, p. 16) era compartilhada por muitos educadores e escritores ao redor do mundo; foi em torno dessa ideia que nasceu a primeira biblioteca infantil internacional, em Munique, em 1949, idealizada por Jella Lepman (1891-1970), jornalista e autora alemã de origem judia, que conseguira escapar das perseguições nazistas e se refugiar em Londres. Com o fim da guerra, Jella volta à Alemanha e toma para si a missão de promover a compreensão internacional através do intercâmbio de livros para crianças. Ela consegue angariar o apoio de importantes autores infantis como Astrid Lindgren, criadora de Pippi Meialonga, e Erich Kästner, autor de Emil e os detetives, e em 14 de setembro de 1949, a International Youth Library abre as portas com um acervo de oito mil títulos. Quando, em janeiro daquele ano de 1949, Cecília Meireles manifesta sua aspiração de ver criada uma biblioteca infantil universal que promovesse o 
entendimento entre crianças de diferentes culturas, ela ainda não havia escrito a coletânea de poemas Ou isto ou aquilo (1964), e talvez não se imaginasse no acervo de uma biblioteca internacional infantil que estaria aberta oito meses depois. Mas hoje, entre os mais de 600 mil títulos (em 130 línguas) à disposição das crianças que visitam a biblioteca, há cinco diferentes edições desse clássico infantil brasileiro, inclusive a rara primeira edição de 1964, da Editora Giroflé, ilustrada por Maria Bonomi, e a também rara edição de 1987, da Nova Fronteira, ilustrada por Fernanda Correia Dias, neta de Cecília Meireles. Tais obras, entretanto, estão em português, acessíveis apenas a falantes de português, e para que haja maior congraçamento entre crianças de diferentes culturas via intercâmbio de obras literárias visando à formação do que Cecília chamou de "humanismo infantill", não seria interessante que as crianças pudessem ter acesso às obras em sua língua materna? ou ao menos em uma língua mais internacional, como o inglês, por meio de tradução?

Movida pelo lirismo, graciosidade, e criatividade dos poemas de Ou isto ou aquilo, eu já havia traduzido alguns, mas a ideia da "unificação de culturas" sonhada por Cecília me fisgou, devido à possibilidade de tornar esse clássico infantil brasileiro acessível também a crianças estrangeiras.

Ao me debruçar mais demoradamente sobre o projeto de tradução, algumas questões foram surgindo: Ou isto ou aquilo é um conjunto poético rico em musicalidade, onde boa parte dos poemas é rimada e metrificada, e outra boa parte brinca com a tessitura da língua portuguesa. O público a que a obra se destina desde cedo teve seu ouvido "treinado" em rimas e ritmo - em acalantos e cantigas de roda entoados pela família ou em jardins de infância - e aprendeu a ter predileção por esses atributos. Preservá-los na tradução deveria então ser uma das prioridades. Como tradutores, sabemos, porém, que para preservar atributos como métrica e rima às vezes não temos outra alternativa senão alterar o conteúdo semântico. Mas, ao alterar o conteúdo semântico, não estaríamos privando os leitores do poema traduzido de chegar à interpretação que os leitores do poema original poderiam fazer? E não estaríamos, então, prejudicando o intercâmbio e o entendimento entre crianças de diferentes culturas - um dos nossos objetivos -, lembrando o preceito-guia "se todas as crianças se entendessem, talvez os homens não se hostilizassem"? Afinal, o que é fundamental para haver entendimento entre leitores de um “mesmo" poema, reescrito em diferentes línguas? Para que crianças se entendam, é preciso que elas cheguem à mesma interpretação?

Essa última indagação nos traz à lembrança a "metáfora do canal", como postulada por Michael Reddy no ensaio "The conduit metaphor", de 1979. Reddy (1979, p. 286-287) 
demonstrou que a estrutura da língua inglesa (e, por analogia, a da portuguesa) induz seus falantes a acreditarem que a linguagem é um canal, e as palavras são containers, receptáculos. Assim, um emissor poderia "colocar" pensamentos e ideias em palavras, e estas, após deslizarem pelo canal-linguagem, chegariam ao receptor, que dessas palavras-receptáculos “extrairia” seu "conteúdo", intacto.

Porém, se admitimos que "o texto é um potencial de efeitos que se atualiza no processo da leitura" (ISER, 1996, p. 15, grifo nosso), estamos admitindo também que cada leitor atualiza o texto conforme seu próprio repertório, constituído de tudo o que ele já leu, viu, ouviu e viveu. Em suma, apesar de continuarmos usando verbos, imagens e expressões da "metáfora do canal", hoje admitimos que diferentes leitores podem vir a se sensibilizar distintamente diante de um mesmo texto, e quase certamente o interpretarão (atualizarão) no processo de leitura de maneira distinta, de acordo com sua subjetividade. E se um mesmo texto pode gerar diferentes interpretações em leitores de uma mesma língua e cultura, o que dizer, então, de textos recriados em outras línguas? Então, será que isso significa que o objetivo de gerar entendimento entre crianças de diferentes culturas por meio do intercâmbio literário via tradução é uma completa 106 utopia? Retomando, então, a questão inicial, será que, para que o desejado entendimento se dê, é preciso que as crianças entendam as obras da mesma maneira e cheguem à mesma interpretação?

É fato que num contexto social, discutindo e refletindo em grupo sobre as leituras individuais (subjetivas) decorrentes de um mesmo texto, é possível decantar as diferentes possibilidades interpretativas e chegar a patamares semelhantes entre os leitores, mas talvez o desejado entendimento de que falava Cecília se dê exatamente pelo contrário: pela conscientização da existência de diferentes línguas, culturas, interpretações e visões de mundo, e de que essas diferentes culturas, interpretações e visões de mundo podem coexistir sem suscitar hostilidades. Em outras palavras, o acesso a diferentes literaturas oriundas de diferentes culturas pode deixar os leitores mais aptos a conviver com o diferente, e a acolher a diversidade com naturalidade. Nesse caso, seria interessante, então, que a tradução não fosse totalmente domesticadora, e não camuflasse de todo a própria origem, permitindo algum grau de estranhamento, ou estrangeirização, para que o leitor-estrangeiro entrevisse algo da culturafonte no texto-alvo.

Desde que comecei a traduzir os poemas de $\mathrm{Ou}$ isto ou aquilo para o inglês, a ideia sempre foi manter algum toque de brasilidade onde possível, com a pretensão de dar a conhecer às crianças estrangeiras algo do Brasil. Ocorre que, com poucas exceções, os poemas dessa 
coletânea são universais nos temas, e seu ponto forte, em se tratando de "brasilidade", é a própria sonoridade e tessitura da língua portuguesa, como visto nos seguintes exemplos: o poema "Enchente" mimetiza o ruído da chuva ao fazer uso de fricativas como "x", "ch", "ge": "Chama o Alexandre! Chama!”, "Olha a chuva que chega!”, “Olha a chama! olha a chispa! olha a chuva nos feixes de lenha!" (MEIRELES, 2012, p. 31); já "Rômulo rema" constrói um tipo de trava-línguas imagético focando nos "Rs": "Rômulo rema no rio", "A romã rubra dorme, cheia de rubis", "Rolam rubis rubros do céu" (MEIRELES, 2012, p. 23).

$\mathrm{Na}$ tradução de poemas como os citados, a balança entre domesticação e estrangeirização fatalmente pende para a domesticação, pois o tradutor se sente instado a reproduzir, com o idioma de chegada, a brincadeira com a tessitura do idioma de partida, já que esse é o atributo mais eloquente no poema de partida. Foi o que tentei fazer com "Enchente" (DINIZ, 2012, p. 167): privilegiei chiantes para reproduzir o som da chuva do poema fonte por exemplo, o título "Enchente" ficou "Flash flood", o verso "Chama o Alexandre!" tornouse "Go fetch Alexandre!" e "Olha a chuva que chega", "Watch the rain approach!", numa tentativa de reproduzir os chiados e respingos da chuva por meio dos sons "sh", "tch" e "ch". Assim, a marca de "estrangeirização" (ou brasilidade) pode ser notada apenas no nome “Alexandre", e somente se este for pronunciado como é em português, com som de "ch", já que em inglês a pronúncia seria algo próximo a “Alegkzander”, não ecoando o ruído da chuva. Mas os leitores ingleses talvez intuam que o Alexandre do poema é pronunciado de outra forma se ele for grafado em itálico. O uso de itálico, aliás, foi adotado pela tradutora Sarah Rebecca Kersley (minha parceira na tradução dos poemas de Ou isto ou aquilo) ao conservar em português o nome da fruta "romã" no poema "Rômulo rema": "The reddening romã rests, filled with rubis". Para reproduzir o trava-línguas com o "R" que permeia todo o poema, Sarah optou por domesticar o nome "Rômulo" para "Rowland" - ótimo achado, pois esse nome de origem inglesa traz em si a atividade de remar, "to row", e o primeiro verso do poema traduzido ficou "Rowland rows on the river". Como o nome do personagem foi domesticado, o toque de estrangeirização ficou por conta da fruta "romã": destacá-la com itálico é a dica para os leitores de que se trata de nome estrangeiro.

"As meninas", poema de que trato neste artigo, guarda algumas semelhanças com os citados acima: universal no tema, é melodioso e brinca com as sonoridades vocálicas comuns nas línguas de origem latina. Além disso, é rimado e segue um padrão métrico, mas nada nele remete a algo definitivamente brasílico, a não ser os nomes das meninas, Arabela, Carolina e Maria, que eu deveria procurar manter se quisesse conservar algo de brasilidade. 
As leituras das crianças na Inglaterra me surpreenderam no que concerne às ilações que fizeram a respeito de Maria, mas não foi o nome dela que gerou as maiores discussões e perplexidades (tanto nas crianças quanto em mim, ao ouvir as crianças), mas o que Maria diz no poema traduzido. Antes, porém, de abordar a recepção das crianças estrangeiras à minha proposta de tradução, é preciso esclarecer alguns pontos sobre a tradução, e algumas de minhas opções tradutórias.

\section{Traduzindo "As meninas"}

Quando Sarah e eu começamos as traduções dos poemas de Ou isto ou aquilo, adotamos como diretrizes alguns princípios usados por tradutores-poetas brasileiros atentos à tradução da forma, entre eles Paulo Henriques Britto, Alípio Correia de Franca Neto, Haroldo de Campos, e Mário Laranjeira (DINIZ, 2012, p.111-132). Segundo Franca Neto (2008), antes de começar a tradução de um poema, o tradutor precisa fazer "um escrutínio severo do original" para identificar os "expedientes da poética do autor", ou seja, os efeitos poéticos que o autor ou a autora privilegiam, em todos os níveis textuais: semântico, sintático, fonético, prosódico,

108 rítmico, etc. Uma vez identificados tais efeitos, o tradutor deveria, então, segundo Britto (2002, p. 54), "recriar, utilizando os recursos da língua meta, os efeitos de sentido e forma do original - ou, ao menos, uma boa parte deles", o que levaria a uma satisfatória relação de analogia e correspondência entre os poemas de partida e de chegada, de modo que o leitor do poema de chegada pudesse ter a ilusão de estar lendo o poema de partida (BRITTO, 2012). No entanto, como é quase impossível obter correspondência em todos os níveis, o tradutor deveria hierarquizar os atributos, e reproduzir ao menos os mais eloquentes.

Além da preocupação com a reprodução dos atributos poéticos e com eventuais perdas semânticas e formais que poderiam ceifar parte da beleza do poema ceciliano, havia também a questão da recepção, uma vez que traduções para o público infantil apresentam um complicador: a relação assimétrica (maturidade, bagagem cultural e linguística) entre as crianças leitoras e os adultos que escrevem ou traduzem para elas (AZENHA, 2008). Para reduzir essa assimetria e garantir a aceitação da obra junto ao público, é recomendável que os tradutores procurem se "aproximar da linguagem do tempo para o qual traduzem", segundo Azenha (2005, p. 380). É recomendável também, quando possível, averiguar a aceitação do trabalho diretamente com o público leitor, "lendo rascunhos de suas traduções para crianças", segundo Lathey (2016, p. 29). O trabalho que ora apresento é uma tentativa nesse sentido, uma vez que as crianças não só leram o poema traduzido, como discutiram algumas de suas nuanças 
detalhadamente, como será visto mais adiante. Para que o caro leitor tenha uma ideia das eloquências e atributos poéticos de "As meninas", apresento, a seguir, o poema original em português ao lado da proposta de tradução para o inglês. As análises e explicações vêm a seguir.

\section{As meninas}

Arabela

abria a janela.

Carolina

erguia a cortina.

E Maria

olhava e sorria:

"Bom dia!"

Arabela

foi sempre a mais bela.

Carolina

a mais sábia menina.

E Maria

apenas sorria:

"Bom dia!"

Pensaremos em cada menina que vivia naquela janela; uma que se chamava Arabela, outra que se chamou Carolina.

Mas a nossa profunda saudade é Maria, Maria, Maria, que dizia com voz de amizade: "Bom dia!"

\section{Girls at the window}

Arabelle

would open the window.

Caroline

would pull up the blinds.

And Maria

would smile from ear to ear:

"Good morning, dear!"

Arabelle

was the prettiest girl.

Caroline

had the cleverest mind.

And Maria

just smiled from ear to ear:

"Good morning, dear!"

We'll miss each girl-at-the-window

they will always be on our mind:

one who was called Arabelle,

another who was called Caroline.

But our heart's deepest longing

is Maria, Maria, Maria,

who used to greet us so lovingly:

"Good morning, dear!"

O poema "As meninas" revela dois momentos na vida do sujeito poético e das meninas Arabela, Carolina e Maria. O primeiro momento é composto das seis primeiras estrofes: somos apresentados às meninas por esse eu lírico que parece um narrador onisciente; os verbos estão no passado, e os versos e estrofes são curtos, como se o tempo tivesse passado rápido demais. O primeiro verso de cada estrofe é o próprio nome da menina, de três sílabas, com quem o segundo verso, de cinco sílabas, rima: Arabela com 'janela' e 'bela', Carolina com 'cortina' e 'menina', e Maria com 'sorria' e 'bom dia'. Enquanto Arabela e Carolina são acompanhadas de verbos de ação, e parecem mais assertivas ao 'abrir a janela' e 'erguer a cortina', Maria parece mais plácida, pois apenas 'olha e sorri'. Enquanto as estrofes de Arabela e Carolina têm 
dois versos, as de Maria têm três: o terceiro verso repete sua fala, "bom dia". Das meninas, Maria é a única a ter voz, ao lado do eu lírico que, já no segundo momento do poema, torna-se também personagem, ao assumir a primeira pessoa do plural e revelar que "pensaremos em cada menina", mas "nossa profunda saudade" será especialmente de Maria, que tinha "voz de amizade".

Nesse segundo momento do poema, as estrofes e os versos são mais longos, com nove sílabas (exatamente a soma do primeiro e do segundo verso das estrofes anteriores), talvez indicando que o tempo da ausência é mais longo do que aquele primeiro tempo, efêmero, em que as meninas estavam presentes. As estrofes, agora de quatro versos, continuam rimadas. Não há dúvidas de que um dos atributos poéticos mais eloquentes deste poema são as rimas, e se quisermos que a versão em inglês seja uma representante do poema fonte na língua de chegada, deveríamos reproduzi-las.

Além da aparente simplicidade e das rimas completas, outro ponto a chamar a atenção é a amabilidade de Maria. Embora ela não seja brindada com um superlativo - como a mais bela Arabela e a mais sábia Carolina - somos levados a crer que Maria seria a mais amigável 110 ou mais empática das três, impressos em seus gestos e fala. Fazendo uma analogia com o projeto sonhado por Cecília Meireles - o de promover o entendimento e a paz entre os povos via intercâmbio literário -, a personagem Maria é aquela que mais o incorporou, por olhar além da janela e de si, enxergar o outro e reconhecer a existência desse outro com um "bom dia". Levamnos a essa leitura a ordem das estrofes e os atos das meninas: se Arabela abre a janela e Carolina ergue a cortina, a ação atribuída a Maria, "olhava e sorria”, também deve estar ligado à janela, donde depreendemos que Maria enxergava quem estava do outro lado da janela.

Dentre as qualidades beleza, inteligência e empatia, o eu lírico parece preferir esta última, pelo destaque dado a Maria. Muitas crianças que leram esse poema tanto nas vivências feitas no Brasil quanto na Inglaterra perceberam a preferência por Maria também na forma do poema, e chamaram a atenção para o fato de o nome dela ter sido dito mais vezes - cinco, enquanto os nomes das outras é dito três vezes. Notaram também que Maria tem uma estrofe só dela (a última), enquanto Arabela e Carolina compartilham, entre si, uma mesma estrofe (a penúltima).

O que mais nos é dado saber sobre as meninas? Que elas não estão mais onde costumavam estar, pois o sujeito poético diz que sentirá saudade de cada uma que "vivia naquela janela". Inferimos que haveria uma relação entre elas: embora em nenhum momento seja dito que eram irmãs, o fato de viverem "naquela janela" indica que era uma mesma janela, 
o que nos leva a pensar que seriam irmãs, a não ser que se tratasse de um colégio ou orfanato, onde elas conviviam.

Já foi dito que as rimas são uma das características mais marcantes desse poema, e, como visto, elas se fazem com os nomes das meninas, nosso grande dilema. Historicamente, a prática geral, em se tratando de literatura infantil, tem sido a de localizar (adaptar) as marcas culturais, isto é, adaptar nomes, alimentos, moeda, para a cultura de chegada, com vistas a aproximar a obra do leitor infantil e reduzir o risco de afugentá-lo (LATHEY, 2016, p. 38). Porém, o dilema quanto aos nomes das meninas nesse poema não foi o estranhamento que eventualmente causariam - mesmo porque um dos propósitos era deixar entrever certa "brasilidade" -, mas a escassez de palavras com tais sonoridades ["ela", "ina", "ia"] em inglês e a consequente dificuldade em rimar os nomes.

Minha disposição inicial era a de manter todos os nomes como no original também porque, segundo depoimento da neta de Cecília Meireles, os nomes Arabela e Carolina eram codinomes usados pelas filhas de Cecília na infância, quando brincavam de teatro (CORREIA DIAS, 2002, p. 355). Porém, manter os nomes no original comprometeria a ludicidade, já que não consegui rimas razoáveis para eles. Adotei, então, a estratégia do decalque, isto é, para Arabela e Carolina usei a grafia (e pronúncia) mais comum na cultura de chegada, a saber, Arabelle e Caroline, mas mantive o nome Maria na pronúncia e grafia como em português, "Mareea" (e não Mary); essa decisão foi fundada também na percepção de que esse nome era objeto de afeto da autora, que o deu às suas três filhas - Maria Elvira, Maria Mathilde e Maria Fernanda. Ao trabalhar na estrutura rímica das estrofes de Maria, achei que havia conseguido um efeito razoável acrescentando "dear" ao seu "Bom dia!" - "Good morning, dear" -, e também tornando largo o seu sorriso, de orelha a orelha, "smile from ear to ear", pois com isso obtive rimas entre "Mareea", "ear" e "dear", como visto na terceira, sexta e oitava estrofes do poema traduzido. Além disso, me encantou a semelhança sonora entre "dia" e "dear", e me convenci de que havia adotado uma boa saída. Não consegui, porém, reproduzir a métrica do original nas estrofes da Maria em função dos acréscimos que fiz. Entretanto, como a métrica das estrofes de Maria no poema fonte são mais longas do que as estrofes das outras meninas (anunciando que Maria era diferente das outras duas), considerei que a estrofe de Maria poderia fugir à métrica não só em relação às estrofes de Arabela e Carolina na versão, mas também em relação às estrofes da Maria no poema fonte.

Quanto à estratégia do decalque em relação aos nomes Arabela e Carolina, "Arabelle" se justifica pelo eco sutil: no dístico "Arabellel was the prettiest girl", os vocábulos "girl" e 
"belle" são mais próximos em sonoridade do que "bela" e "girl" (se mantido o nome original, Arabela). Algo semelhante se deu no caso de "Caroline" ("Keroláine"): "blinds" (persiana) e "mind" (mente, intelecto) não formam rimas completas com "Caroline", mas têm sonoridade bem próxima, e suprem de maneira razoável o esquema rímico original, lembrando que em inglês é bem comum o uso de rimas incompletas: "Caroline/ had the cleverest mind".

O uso do "would" como passado contínuo se justifica em vista da ideia de hábito que se repete no passado; uma alternativa teria sido "used to": "Caroline/ used to pull up de blinds".

Já a opção por traduzir o título "As meninas" por "Girls at the window" se justifica como estratégia de compensação. É que o acréscimo da expressão "from ear to ear" na tradução do verso "olhava e sorria" tornava-o demasiado longo "[And Maria] would glance and smile from ear to ear". Optei, então, por omitir o verbo "olhava/would glance", mas julguei que tal omissão poderia levar os leitores do poema traduzido a não fazerem conexão entre Maria e a janela. Ao explicitar, já no título, a conexão entre todas as meninas e a janela, tentei suprir a falta do correspondente "would glance" para o "olhava" original. Com o título "Girls at the window", julguei que a conexão entre Maria e a janela estava feita. Porém, a questão da relação

112 entre Maria e "os outros” continuava: será que as crianças estrangeiras veriam Maria como uma criança dotada de empatia, que enxergava o Outro, algo que a meu ver era uma das intenções da autora? A resposta a esta questão, além de tantas outras interpelações levantadas pelas crianças, é o que veremos a seguir, nos resultados.

\section{As leituras das crianças via Pensar Alto em Grupo}

As vivências foram realizadas seguindo as diretrizes da prática de letramento dialógica e colaborativa Pensar Alto em Grupo (ZANOTTO, 2014), pesquisada pelo Grupo de Estudos da Indeterminação e da Metáfora (GEIM), da PUC-SP, coordenado pela pesquisadora Mara Sophia Zanotto, uma das criadoras dessa prática, e pioneira no seu uso em pesquisas com leitura de poesia e prosa poética. A ideia é que a leitura seja feita coletivamente de maneira que o entendimento vá sendo construído a partir dos questionamentos e considerações feitos em voz alta pelos participantes. Os aportes de um podem ajudar a esclarecer as dúvidas de outro; quando isso não ocorre, sempre se pode recorrer a dicionários ou pesquisar em outros meios, e voltar ao texto, relendo o todo ou alguns trechos, diante de algum impasse.

O Pensar Alto é uma prática de inspiração freireana, com caráter dialógico e orientação horizontal, isto é, todos os participantes se inscrevem na interpretação do poema, à medida que 
aportam seu conhecimento, suas hipóteses e inferências, no processo de tentar solucionar lacunas ou desvendar metáforas, por exemplo.

No início das sessões, eu entregava a cada criança uma folhinha com o poema impresso. Elas o liam em silêncio duas ou três vezes e depois ouviam um áudio do poema gravado por um nativo da língua, antes de lerem, elas mesmas, o poema em voz alta. Algumas vezes a audição do poema foi feita antes da leitura, mas em todos os casos as crianças leram, ouviram e recitaram o poema mais de uma vez.

As crianças tinham entre nove e dez anos à época das vivências: as brasileiras estudavam no $4^{\circ}$ ano da EMEF Vera Lúcia Fusco Borba, na cidade de São Paulo, e as estrangeiras no correspondente Y5, na Inglaterra: um dos grupos estudava na Thriplow Primary School, na zona rural de Cambridge; o outro, na King David Primary School, na cidade de Birmingham. O grupo de Thriplow era composto de nove crianças: sete meninas e dois meninos, todos brancos, cristãos anglicanos, e nascidos na Inglaterra, exceto duas irmãs gêmeas, nascidas na Nova Zelândia. O grupo de Birmingham era composto de cinco meninos e cinco meninas: oito crianças muçulmanas (descendentes de imigrantes paquistaneses, árabes e bósnios) e duas crianças judias (um menino inglês e uma menina de pais caribenhos). O grupo brasileiro também tinha dez componentes: quatro meninos e seis meninas, em que quatro crianças eram negras e seis brancas, todas cristãs, entre evangélicas e católicas. Os nomes de todas as crianças foram trocados para proteger sua privacidade.

Destaco, a seguir, blocos individuais com observações que os grupos escolares fizeram em relação ao poema de partida, "As meninas" (brasileiras), e ao de chegada, "Girls at the window" (estrangeiras). Ao final dos blocos com as observações infantis, teço alguns comentários. Todos os dados foram gerados enquanto eu desenvolvia minha tese de doutorado. Doravante, todas as menções a páginas, quando não acompanhadas de autoria, são referentes à tese, encontrada na Bibliografia sob a rubrica DINIZ, 2018.

\subsection{Sobre a forma do poema e de como (se) destaca Maria}

Vera Lúcia Fusco Borba: Questões relacionadas à forma do poema foram as primeiras observações feitas pelas crianças brasileiras após a leitura de "As meninas". Uma das participantes, Ana Elis, observa que é um poema rimado; na sequência, todas as crianças passam a listar as rimas: "Arabela, bela, janela, Carolina, menina, Maria, sorria...” (p. 535). Aurélio comenta que o poema parece dedicado à Maria, pois fala mais dela; as outras crianças então percebem que o nome da Maria é mencionado cinco vezes, enquanto os nomes de Arabela 
e Carolina são mencionados apenas três vezes. (p. 537-541). Léo então associa a frequente menção à Maria como preferência: "Eu acho que eles gostam mais da Maria porque fala o nome dela mais vezes” (p. 538). Kaíque concorda: “O poema parece que foi feito pra Maria, né?” (p. 540). E embora Cecília Meireles não tenha agraciado Maria com superlativos, como fizera com Arabela e Carolina, as crianças, por analogia, o fazem: para Nayara, "Maria era a mais feliz porque ela sempre sorria" (p. 549); para Sophie, Maria sorria todo dia, então "ela era a mais alegre" (p. 550); já Ana Elis viu nessa característica o motivo para sentirem saudade de Maria: "as pessoas se alegravam com a felicidade dela, por isso sentiram falta" (p. 550). E para quem, afinal, Maria sorria e dava "bom dia"? Segundo Nayara, ela sorria "para as pessoas que passavam na rua" (p. 547); já Sophie acha que Maria falava "bom dia" para as irmãs (p. 548); para Valéria, ela falava "para as pessoas" (p. 548); segundo Aurélio, "para os primos, tios, avó, bisavô..."

Thriplow: Após lerem "Girls at the window", as crianças de Thriplow não chegaram a mencionar nenhuma rima, como as brasileiras tinham feito, mas Hazel nota que Maria tinha uma estrofe só dela, enquanto Arabelle e Caroline compartilhavam uma estrofe entre si. Tal 114 constatação leva Hazel a agraciar Maria com um superlativo, "a mais importante", e comparála à lendária enfermeira Florence Nightingale, que socorreu feridos na Guerra da Criméia (p. 600); Jewel e Jesslyn concordam, e também afirmam que os pais decerto gostavam mais da Maria, já que no poema ela tinha "uma quadrinha só dela" (p. 600); para April, Maria seria “a mais responsável” (p. 591) e "a mais madura" (p. 600), porque cumprimentava carinhosamente ["lovingly"] com "good morning, dear". Quanto à expressão "smile from ear to ear" [sorrir de orelha a orelha], para Hazel, ela significa que Maria sorri para todos, "não deixa de sorrir para ninguém" (p. 602); para April, é sinal de que "ela é a mais feliz" (p. 602), e sempre "traz um sorriso no rosto".

King David: Após recitarem "Girls at the window” em voz alta várias vezes, as crianças de Birmingham observaram que se tratava de um poema rimado (p. 624): Aleeza e Amnyaan apontaram a rima entre "dear" e "ear", e Tom acrescentou "Maria" à lista de rimas, afirmando que o modo como o nome Maria é pronunciado ("Mareea") rima com “dear" e "ear" (p. 624). Munir, Tom e Avivah chamam a atenção para a rima entre "Caroline" e "mind" (p. 625), com a qual Amnyaan não concorda, pois, para ela, tais palavras "soam como se rimassem, mas não rimam" (p. 626). Por fim, Zaheen também afirma que “dear" e “ear" rimam (p. 628). Embora tenham notado as rimas, as crianças desse grupo aparentemente não perceberam que Maria tinha uma estrofe só dela (como as crianças de Thriplow tinham notado), nem tampouco que 
seu nome era mencionado com mais frequência do que os nomes de Arabelle e Caroline (como fizeram as crianças do Brasil). Ainda assim, Maria transpareceu como a personagem mais marcante, pois a discussão girou em torno dela a maior parte do tempo (como será visto no tópico 2.2).

\section{Considerações sobre a leitura da forma}

A questão da percepção das rimas e de outras características formais é importante pela experiência estética em si, que os leitores do poema traduzido idealmente deveriam poder experimentar, tanto quanto os leitores do poema fonte, mas é importante também para o entendimento da função estética: a conscientização de que autores recorrem a efeitos poéticos para de alguma forma tocar o leitor, ou para lhe fornecer uma chave. Quando o leitor adquire essa consciência, ele pode, por inferência, passar a perscrutar os efeitos em busca de uma chave (como aconteceu com as crianças brasileiras e as de Thriplow), ou pode apenas fruí-los se concluir que estão ali basicamente pelo efeito em si. Tal consciência também representa outro estágio do letramento literário, que inclui a feitura do poema: a leitura levando o leitor à escritura.

No caso de "As meninas", o poema fonte possibilitou que as crianças brasileiras se divertissem com as rimas: por iniciativa própria, elas brincaram de mudar os próprios nomes para rimar como Carolina: Nayara tornou-se Nayarina; Aurélio, Aurelina; Leonora, Leonorina etc (p. 545). A ludicidade do poema fonte estava bem à mostra, e embora algumas crianças brasileiras (assim como algumas estrangeiras) tenham interpretado que "as meninas da janela" tinham morrido, a suposta morte não toldou o poema para as brasileiras, que não deixaram de ver alegria nele: para Sophie, por exemplo, o poema é feliz "porque tem um monte de 'sorria"” (p. 540); para Nayara, "rima dá mais vida ao poema" (p. 443). Já a escassez de rimas no poema traduzido pode ter enfraquecido o lado brincante, fazendo com que a face melancólica prevalecesse, contribuindo para que as crianças estrangeiras interpretassem o poema de maneira bem mais séria e dramática, como veremos no próximo tópico.

\subsection{Sobre questões semânticas, a idade das meninas e a relação entre elas}

Vera Lúcia Fusco Borba: Entre as crianças do grupo brasileiro, prevaleceu a ideia de que as meninas eram crianças e irmãs. Na tentativa de justificar a saudade que o sujeito poético sente das meninas, Nayara comenta que "parece que a Maria morreu” (p. 540); Léo, assim como Leonora, acha que ela "mudou de cidade" (p. 540). Aurélio toma os verbos no passado como 
pista textual, e passa a achar que Maria morreu: "Pensaremos em cada menina que vivia naquela janela. Que VIVIA, então quer dizer que ela morreu", diz ele (p. 543). Valéria e Léo imaginam que elas devem "ter amadurecido" e "ficado adultas e pararam de ficar na janela" (p. 543), revelando que ao menos na primeira parte do poema, quando o sujeito poético fala no passado, as meninas eram crianças. Nayara comenta que elas deviam ser irmãs, pois "cada uma fazia uma tarefa [na janela]” (p. 546), com o que concordam Sophie e Janaína. Já Léo, ao explicar por que gostou mais de Carolina, diz que é porque ela fazia as tarefas "que a mãe pedia", enquanto "Maria só ficava sorrindo na janela e dando bom dia" (p. 552), dando a entender que as meninas tinham a mesma mãe, e, portanto, seriam irmãs.

Thriplow: As crianças do grupo Thriplow me surpreenderam com sua certeza férrea: Gwen e Hazel afirmaram, logo no início da vivência, que as três meninas seriam irmãs e Maria seria a mais velha delas (p. 590). Demonstrei estar intrigada com a interpretação de Maria ser a mais velha, e April explicou que Maria tinha um jeito maternal, entrevisto naquilo que o poema diz sobre ela: alguém que "cumprimentava com carinho" ["greeting us so lovingly"], mas também na própria fala dela, que dizia "Good morning, dear". Segundo April, "pais até 116 falam pros amigos 'bom dia, queridos', mas crianças só falam 'bom dia”” (p. 591); Gwen então confirmou que crianças não falam "dear" (p. 591). As meninas foram vistas como crianças também por Ben (p. 593), Pam (p. 595), Jonathan (p. 596), e Lizzie (p. 597), em diferentes momentos da vivência, mas, devido ao "dear", que eu havia acrescentado para compor rima com "Maria" e com "from ear to ear", Maria já não era mais criança, e sim a irmã mais velha, que cuida das outras duas, essas, sim, crianças. Maria seguirá se transformando com o decorrer das discussões, como veremos.

Antes de voltarem a falar na idade da Maria, as crianças passam a refletir sobre quem seria o "narrador" do poema, e por que tal narrador usaria a primeira pessoa do plural ["we will miss each girl-at-the-window"], e não do singular, e então pipocam ideias: Jonathan sugere que o poema se passa na época da Segunda Guerra e as meninas são vítimas de um bombardeio. Vale notar que a vivência desse poema ocorreu na semana em que se celebra o Remembrance Day, 11 de novembro, quando na Inglaterra são homenageados os soldados que pereceram em batalha, o que pode explicar o fato de Jonathan ter situado o poema na época da guerra. Segundo Jonathan, o pai das meninas estaria no front, lutando; quando ele volta da guerra, as meninas já morreram. Assim, para Jonathan, quem sente saudade e narra o poema é o pai e os amigos do pai (p. 596), enquanto para as outras crianças, talvez fossem as tias e primas das meninas (p. 598), ou o pai e a mãe das meninas (p. 596), ou habitantes da mesma cidade, que gostavam de 
ver as meninas na janela, como disseram Hazel (p. 597) e Ben (p. 593); para este último, as meninas não morreram, mas mudaram de cidade para ir para a faculdade (p.593). É bom lembrar que o poema tem dois momentos: o primeiro com verbos no passado, e o segundo no presente, e entre esses dois momentos há uma enorme lacuna que as crianças tentam preencher com dados do poema e com suas próprias ideias e experiências. Assim como também aconteceu no Brasil, algumas crianças interpretaram que as meninas morreram; outras, que elas cresceram e mudaram seu jeito de ser, ou mudaram de cidade.

Baseada nos argumentos sobre a fala da Maria ser "maternal", Jewel sugere que Maria seria a mãe de Arabelle e Caroline (p. 599); April concorda. A troca de ideias continua, e Hazel chama a atenção para o fato de Maria ter uma estrofe só dela (p. 600), indício de que sua família a via como "mais importante". Nesse momento April nota que o título do poema é "Girls at the window", volta atrás, e afirma que Maria não pode ser a mãe, pois, se fosse, o título seria "Girls and Mom" (p. 600). April, então, rearranja suas ideias e conclui que o poema se passa "no tempo antigo": Maria seria a mais velha e "mais madura" das meninas, e diria "Good morning, dear" para as irmãs; ou então ela seria uma governanta - personagem relativamente comum na literatura inglesa de cem anos atrás. Nesse momento Jewel também volta atrás, concorda com April, diz que as três são crianças e irmãs e os pais deviam preferir Maria, pois ela tem uma estrofe só dela. Jesslyn concorda: por ter uma estrofe própria, Maria era a favorita dos pais, ou então ela foi a que viveu mais ["the longest living one"]. Ao ouvir isso me convenço de que as crianças estavam interpretando "longing" ["saudade", no verso "our heart's deepest longing”] como "longevidade": por isso diziam que Maria era "a que viveu mais". Enquanto procuravam no dicionário o significado de "longing", Hazel, que disse saber o que era, explica e dá exemplos: ““longing' significa 'querer que a pessoa esteja lá', 'longing' é 'ansiar', 'querer' (p. 602); no caso do Menino Azul, ele ansiava por um burrinho, porque ele queria um burrinho", ela diz (p. 601). Vale notar que esse mesmo grupo tinha lido a tradução de "O menino azul”, de Cecília Meireles, intitulado "The Blue Boy", na semana anterior.

Com "dear" e "longing", eu tinha dois exemplos de decisões tradutórias não muito bemsucedidas: o "dear" na fala de Maria, que levou as crianças a verem-na como a mãe, ou governanta, ou irmã mais velha de Arabelle e Caroline; e "longing”, por ser substantivo de registro mais alto e de uso incomum para a faixa etária em questão, transformara Maria na figura "mais longeva", segundo as crianças que desconheciam o significado de "longing". Embora 'saudade' possa ser traduzida por "longing”, o mais comum para falar desse sentimento em inglês é usar o verbo "miss", como no verso "we will miss each girl-at-the-window". 
Quanto à expressão "smile from ear to ear", que eu também introduzira no poema traduzido em nome da rima, e que julgara de uso comum, as crianças demonstraram desconhecê-la e a interpretaram conforme o contexto e a literalidade: para Hazel, significava que Maria sorria na orelha de uma, e na orelha de outra, "quer dizer, de uma pessoa para outra, e não deixava de sorrir para ninguém” (p. 602), semelhante à definição dada por Pam: Maria iria falando "bom dia" e sorrindo de pessoa em pessoa, para todos (p. 603). Já April disse que significava que Maria era "a mais feliz de todas", aquela que tinha "sempre um sorriso no rosto" (p. 602). Essa sessão de pensar alto sobre "Girls at the window" mostrou que "smile from ear to ear", apesar de ser uma solução graciosa, não era muito adequada para aquela faixa etária, ainda que as crianças a tenham interpretado razoavelmente bem, dentro do contexto.

King David: O grupo de Birmingham também me surpreendeu com as ilações que fizeram a partir do aparentemente inofensivo e afetuoso termo "dear". Diferentemente do grupo de Thriplow, porém, em Birmingham uma das crianças, Tom, começou a conversa exatamente a partir do "problemático" "longing", e o fez de uma forma tão didaticamente natural, que todo o grupo pareceu compreender ou ao menos intuir seu significado. Segundo Tom, o poema lhe 118 parecia triste porque "our heart's deepest longing" dá a ideia de que "a gente vai sempre se lembrar quando [as meninas] morrerem" (p. 625-626); e, como os verbos estão no passado, Tom conclui que elas haviam morrido. Algumas crianças (Amnyaan, Aleeza, e Avivah) concordam com Tom quanto à morte das meninas, argumentando que os verbos e ações delas estão todas no passado: "costumava nos cumprimentar", "abria a janela".

Tudo parecia se encaminhar para uma interpretação homogênea, em que as meninas teriam morrido e por esse motivo o sujeito poético sentia saudade. O pensar alto fica mais vívido a partir de uma alternativa sugerida pelo garoto bósnio Munir: as meninas poderiam ter se mudado para outro país (p. 627). Aleeza, que concordara com a morte das meninas no primeiro instante, muda de ideia e abraça essa hipótese, acrescentando que as meninas tinham mudado de país e "não queriam mais voltar" (p. 627). Hameed e Zaheen concordam. Tom continua defendendo a hipótese da morte das meninas com base nos verbos no passado, e na ideia de que elas poderiam continuar a fazer as mesmas atividades no outro país, se estivessem vivas. É então que Aleeza introduz sua hipótese de que Maria teria forjado a própria morte para sair do país. Ela começa e interrompe a frase a meio caminho: "Talvez ela tenha forjado a própria morte para sair do país, porque as pessoas em volta dela...” (p. 629). Munir e Ali Baqir abraçam essa hipótese justificando que Maria estava cansada de dizer "good morning, dear" (p. 630). Tom volta a defender sua ideia de que elas morreram, e discorda que tenham forjado a própria morte, 
pois, segundo ele, elas trabalhavam em equipe e pareciam felizes, "uma erguia a persiana, outra dizia bom dia...” (p. 630). Ali Baqir eleva o tom, discordando dessa placidez: "elas forjaram a morte porque é uma história falsa, e elas forjaram a morte porque estavam cansadas de erguer a persiana, abrir a janela e fingir coisas bonitas” (p. 631). Aleeza concorda, e sugere que Maria não gostava das pessoas à sua volta, pois estas a estariam obrigando a fazer coisas que ela não queria fazer (p. 631). Amnyaan discorda dessa leitura, alegando que "todos pareciam gostar da Maria" (p. 631): no poema Maria parecia "simpática e gentil" e eles "iam sentir a falta de todas as meninas, então sentiriam falta dela também" (p. 632).

Outras crianças, porém, aderem à hipótese da morte forjada, como Zunairah, que sugere que "elas estavam sendo ameaçadas" (p. 633); Zunairah também supõe que as meninas provavelmente não gostavam da escola, pois lá elas eram obrigadas a fazer coisas de que não gostavam, e por isso tinham decidido ir para outro país (p. 635). Hameed então sugere mais uma hipótese: elas não forjaram a própria morte, apenas se separaram, pois tinham "diferentes personalidades, brigaram, e cada uma foi para um lado" (p. 632). Munir, o primeiro a sugerir que elas tinham mudado de país, abraça a hipótese de Hameed. O mesmo faz Ali Baqir, abandonando a hipótese de que elas teriam forjado a própria morte. Ali Baqir até mesmo cria uma cena em que as meninas brigam e Maria grita "Parem de brigar! Cada uma pro seu lado!" (p. 634).

O pensar alto, então, por alguns momentos envereda para a possibilidade de as meninas brigarem e de Maria ser brava [“angry"]. Avivah, Amnyaan, Aleeza e Tom defendem Maria, argumentando que ela parece boazinha ["nice"], não brava (p. 634). Hameed encontra no poema uma pista para justificar que as meninas são irmãs: segundo ele, as três são irmãs porque "elas abriam a janela e erguiam a persiana, o que deve significar que viviam juntas na mesma casa" (p. 635).

Quando pergunto quantos anos eles acham que as meninas têm, Tom diz que Maria deve ter "uns trinta anos", e justifica: "adultos costumam dar bom dia para as pessoas, mas eles precisam falar para os filhos fazerem o mesmo, senão eles não fazem. E quem seria esse 'dear'?", pergunta Tom, evidenciando que a pista textual usada por ele para atribuir a idade de Maria é o "dear". Segundo ele, "se as meninas fossem mães, elas diriam para os filhos 'good morning, dear"' (p. 638). Avivah concorda com Tom e diz que Maria talvez fosse a mãe das outras duas. À lembrança de que o poema é intitulado "Girls at the window", Tom repensa: Maria deve ter "uns quinze anos" (p. 639). 


\section{Considerações sobre a leitura semântica}

Muitas conclusões podem ser tiradas dessas vivências, com suas interpretações surpreendentes. Primeiro, que “dear”, definitivamente não faz parte do vocabulário comumente usado por crianças, como visto nas vivências em Thriplow e Birmingham. Em ambos os lugares, parte das crianças viu Maria como a irmã mais velha ou mãe das outras duas, devido à sua fala maternal. Em Birmingham, porém, o "dear" provocou outro efeito, e levou a uma leitura distinta entre crianças imigrantes/refugiadas que podem ter sido vítimas de perseguição ou opressão em seu país de origem. Como visto, o fato de Maria falar "dear", aliado ao fato de esse uso não ser natural entre crianças, levou três meninas paquistanesas (Aleeza, Zunairah e Zaheen) e também alguns meninos (Ali Baqir e Munir) a concluírem que ela estava sendo coagida a dizê-lo, e talvez estivesse sendo ameaçada e obrigada a fazer outras coisas de que não gostava, não lhe restando outra saída a não ser forjar a própria morte para fugir do país.

Entre as crianças de origem paquistanesa, a única a nunca aderir a essa interpretação foi Amnyaan, que fez uma leitura semelhante à de Tom, menino inglês. Assim como Tom, Amnyaan voltava reiteradamente ao texto para justificar suas opiniões. A garota Avivah, de

120 origem caribenha, fez leitura semelhante à de Amnyaan e Tom, e embora também fosse exilada como as paquistanesas, a questão da opressão (política ou religiosa) talvez não tivesse o mesmo peso em sua história de vida como tinha ou teve na história de vida das crianças oriundas do Paquistão. Observei que quando as crianças paquistanesas argumentavam que Maria estaria sendo ameaçada, ou coagida a fazer coisas que ela não queria fazer, elas nunca terminavam a frase por completo, como se fosse suficiente deixar apenas sugerido - o que me fez pensar que talvez fosse indecoroso citar os atos a que Maria seria obrigada. Não ousei lhes perguntar sobre o que elas evitavam falar, por isso só posso conjecturar que as crianças daquele grupo preencheram a lacuna do que teria acontecido com as meninas com uma história de fuga para outro país devido à sua própria experiência de vida, ou à experiência de vida de alguém muito próximo a elas.

E como explicar o caso da menina Amnyaan? Sua subjetividade e capacidade leitora podem tê-la feito rejeitar a interpretação proposta por Aleeza, por achar que a pista textual (o "good morning, dear" que Maria estaria sendo coagida a dizer, segundo Aleeza) era frágil perante outras pistas que lhe diziam que Maria era feliz e gostava de dizer "dear".

Algo curioso ocorreu no dia seguinte. Quando voltei à escola King David para realizar outra vivência com esse mesmo grupo, Tom quis falar novamente sobre as meninas. Ele contou que tinha relido o poema em casa, e entendido que "Arabelle e Caroline gostavam de ficar na 
delas" ["they are more, like, their own way"], mas Maria era diferente: ela era mais sociável, "gostava de interagir com os outros" ["she is one of those people who interacts with other people"] (p. 326). Perguntei às outras crianças se elas também tinham relido o poema e se queriam acrescentar alguma coisa. Elas responderam afirmativamente à primeira pergunta $\mathrm{e}$ silenciaram em relação à segunda, possivelmente porque estavam satisfeitas com as interpretações que tinham feito, diferentemente de Tom, que ficara intrigado, e tinha refletido um pouco mais. Nem sempre uma vivência é suficiente para certos leitores, ou certos poemas. Há poemas que irão nos acompanhar a vida toda, sem nunca lograrmos seu pleno desvendar. À parte isso, a leitura feita a sós, aquele "contato solitário e profundo que o texto literário pede", segundo Lajolo (1997, p. 15), pode trazer novos insights, como aconteceu com Tom, que surgiu no dia seguinte com uma Maria mais amigável, sociável e feliz. Sua leitura me surpreendeu, pois, como eu havia dito no tópico sobre a tradução, a omissão do verbo "olhava" no poema traduzido me deixava temerosa de que os leitores da tradução não conseguissem ver Maria como uma criança dotada de empatia, que enxergava o outro, algo que a meu ver era uma das intenções da autora. Pois bem, Tom enxergara empatia em Maria, embora o "dear" o tenha feito ver Maria não como criança, mas como uma jovem adulta.

\section{Conclusão}

Comecei este artigo com uma citação de Cecília Meireles, em que ela revela sua "aspiração a uma Biblioteca Infantil que aparelhasse a infância de todos os países para uma unificação de cultura": Cecília tinha esperança de que, se tal biblioteca existisse, talvez as crianças se entendessem e os homens não se hostilizassem. Ao refletir sobre o que seria esse entendimento entre as diferentes crianças leitoras, me perguntei: Caso exista tal biblioteca, e as crianças leiam determinado texto em diferentes traduções, seria essencial que elas o interpretassem da mesma forma? Ou talvez tal entendimento entre leitores derive da conscientização de que é possível haver diferentes interpretações, sem que elas sejam excludentes? Ou de se saber que é possível haver estranhamento, sem que este resulte em hostilidade?

Ao traduzir os poemas de Ou isto ou aquilo, Sarah e eu nos empenhamos em reproduzir os atributos poéticos dos poemas fonte de tal maneira que o poema de chegada fosse um digno representante do de partida, porém deixando aberta uma possível janela para a "brasilidade", além daquela "saudável topada e sacudidela" advindas do contato entre duas culturas, à maneira do que busca Sarah Ardizzone em suas traduções do francês para o inglês (LATHEY, 2016, p. 
95). No poema "As meninas", "brasilidade" e "topada e sacudidela" repousaram no nome Maria.

Vimos, porém, que o nome em si não levou a muitas reviravoltas, mas a fala de Maria, sim, em função do (a esta altura) já tão decantado "dear". Uma vez que crianças não falam “dear", Maria transformou-se, alternadamente, em irmã mais velha, mãe, governanta, outra vez mãe, jovem adulta, criança oprimida e coagida, novamente mãe, irmã adolescente. As metamorfoses de Maria, no entanto, só se deram dessa maneira porque cada indivíduo inseriu no texto lido seu conhecimento de mundo e, ao pensá-lo alto, foi auxiliado pelos colegas, que também pensaram alto suas opiniões: assim, cada um pôde sopesar a opinião própria frente às opiniões dos colegas e discordar destas, reafirmando as próprias convicções, ou concordar com elas e eventualmente mudar de ideia diante de hipótese que lhe parecesse mais plausível.

Uma vez que o poema tem uma grande lacuna, muitas ideias aventadas para explicar a lacuna vieram de algum conhecimento prévio das crianças, associado a pistas textuais. $\mathrm{O}$ incongruente "dear" acabou se tornando uma inadvertida pista textual que levou as crianças de Thriplow a verem Maria como a irmã mais velha ou mãe das outras duas. O fato de a vivência 122 em Thriplow ter sido realizada na semana de celebração do Remembrance Day motivou alguns alunos a situar o poema durante a Segunda Guerra: as meninas Arabelle e Caroline e sua mãe Maria teriam morrido durante um bombardeio, o que explicaria a saudade do sujeito poético, que seria o pai e amigos, ou outros integrantes da família. O mesmo "dear" serviu igualmente de pista textual para as crianças de Birmingham; porém, sendo elas um grupo composto majoritariamente de imigrantes e refugiados, especialmente do Paquistão, as ilações foram outras, e Maria foi vista por boa parte do grupo como uma menina oprimida que estaria sendo coagida a fazer coisas ruins ou de que não gostava, entre elas falar "good morning, dear" para seus próprios opressores.

Neste artigo, abordei a tradução de poesia infantil usando como fio condutor a personagem Maria e sua recepção entre crianças brasileiras e estrangeiras. Perguntei: “Será que, tendo omitido o verbo 'olhava' da estrofe da Maria na tradução, as crianças estrangeiras veriam Maria como uma criança dotada de empatia, com olhos para o outro - algo que a meu ver era uma das intenções da autora?” Vimos que as crianças brasileiras não deram nome à implícita qualidade da Maria, mas não faltaram sinais de que Maria despertou nelas simpatia e bemquerer, pois ela foi considerada "a mais feliz", "a mais sorridente", "a mais alegre", "a de que as pessoas mais gostavam", e aquela que contagiava a todos com sua alegria, pois todos "se alegravam com a felicidade dela". Empatia? 
E quanto aos grupos estrangeiros? As crianças de Thriplow viram Maria como "bondosa", "simpática", “carinhosa”, "responsável”, "maternal”, “a mais feliz”, "a mais importante" (como teria sido a enfermeira Florence Nightingale, segundo Hazel). Algumas dessas qualidades apontam francamente para uma personagem empática e compreensiva. Maria, no entanto, devido ao "dear", também foi vista como a "irmã mais velha" ou a "mãe das outras duas", e isso de certa forma minimiza o alcance da sua empatia, já que é esperado que mães sejam carinhosas e bondosas com suas filhas, assim como se espera que irmãs mais velhas o sejam com as irmãs menores. É bom lembrar, porém, que Maria foi comparada a Florence Nightingale, a quem não deve ter faltado empatia, pois se notabilizou socorrendo feridos na Guerra da Criméia. Pela comparação, infere-se que as crianças viram Maria como dotada de empatia também. O leitor ainda lembra que algumas crianças de King David viram em Maria uma menina oprimida, mas corajosa o suficiente para forjar a própria morte, escapar de seus algozes, e fugir para outro país, em busca de liberdade. Outras crianças desse mesmo grupo também viram Maria como a mãe ou a irmã mais velha de Arabelle e Caroline, e a qualificaram de "simpática" e "amorosa". A surpresa extra veio do pequeno leitor Tom que, ao ler novamente o poema em casa, retornou com a leitura de Maria como a "mais sociável”, uma "pessoa que gosta de interagir com outras pessoas": empatia.

Mas Maria não foi unanimidade. Entre as crianças brasileiras, Léo a viu como uma menina um tanto indolente, que escapava das tarefas domésticas, e só ficava na janela, sorrindo (p. 552). Em King David, Maria passou por insincera: como criança, ela não podia estar sendo sincera ao falar "good morning, dear", segundo Ali Baqir (p. 629). E passou também por intolerante, na versão em que ela se separa das outras irmãs em meio a brigas por terem personalidades diferentes.

Os resultados, semelhantes em alguns pontos e díspares em outros tantos, refletiram o background dos grupos de leitores e a atualização do texto no processo de leitura: leitores de Thriplow imaginaram as meninas em um cenário de guerra, algo que leitores brasileiros dificilmente fariam, uma vez que o impacto da guerra no Brasil foi consideravelmente menor; e leitores de Birmingham imaginaram as meninas como crianças que viviam ameaçadas num lugar opressor, algo recorrente na história de refugiados, mas distante da atual realidade das crianças brasileiras. Leitores e textos transformaram-se uns aos outros em cada encontro. De cada leitura vi surgirem diferentes meninas, especialmente diferentes Marias, que viveu muitas vidas e se multiplicou. Mas embora a Maria surgida no estrangeiro transbordasse empatia (ponto chave no poema, a meu ver), ela deixava de ser menina quando abria a boca para falar 
“dear", o que me levou de volta às recomendações de Azenha (2005, p. 380, grifo nosso), sobre a tradução de literatura infantil:

Como o público receptor está no centro das questões de tradução de literatura infantojuvenil, não é possível se escapar de uma certa aproximação com a linguagem do tempo para o qual se traduz, ressalvadas as limitações impostas pelo enredo e pelas brincadeiras com a linguagem da obra a ser traduzida.

A tradutora quis entrar na brincadeira, mas, em lugar de se aproximar, afastou-se da linguagem do tempo para o qual traduz. Se no passado crianças se tratavam por "dear", como provam os diálogos entre Alice e sua irmã naquela tarde em que a famosa personagem desperta e ouve a irmã lhe dizer "Wake up, Alice, dear! Why, what a long sleep you've had!", agora está claro que esse tempo passou.

$\mathrm{Na}$ impossibilidade de encontrar rimas divertidas para os nomes Maria, Arabela e Carolina sem fazer acréscimos e sem provocar reviravoltas, talvez fosse o caso de abdicar da "brasilidade" nesse poema, domesticar os nomes em troca de outros mais rimáveis, para tentar recuperar a ludicidade, e voltar à brincadeira. Foi o que fez o tradutor Pedro Ribeiro Nogueira (informação pessoal) ao final de um bate-papo sobre tradução de literatura infantil na Casa Guilherme de Almeida, em outubro de 2018:

\author{
Grace \\ would open the window. \\ Caroline \\ would pull up the blinds. \\ And Mae, \\ would glance and say: \\ "G'day!" \\ Grace \\ had the cutest face. \\ Caroline \\ was the wisest mind. \\ And Mae \\ would smile and say: \\ "G'day!" \\ We'll remember each girl \\ that lived in that window; \\ one that was named Grace, \\ the other went by Caroline,
}


but our deepest longing

it's Mae, Mae, Mae,

who friendly and gay, would say:

"G'day!"

Ainda nos resta responder a uma pergunta, feita na Introdução deste artigo: "Será que, para que o entendimento entre crianças se dê, é preciso que elas entendam as obras da mesma maneira e cheguem à mesma interpretação?"

E então?

\section{REFERÊNCIAS BIBLIOGRÁFICAS}

AZENHA, João. A tradução para a criança e para o jovem: a prática como base da reflexão e da relação profissional. Pandemonium germanicum, São Paulo, n. 9, p. 367-392, 2005. Disponível em: http://www.revistas.usp.br/pg/article/view/73944. Acesso em: mar. 2019.

AZENHA, João. Dependências, assimetrias e desafios na tradução para a criança e o jovem no Brasil. In: SCHEYERL, Denise; RAMOS, Elizabeth (org.) Vozes, olhares, silêncios diálogos transdisciplinares entre a linguística aplicada e a tradução. 1.ed. Salvador: EDUFBA, v.1, 2008. p. 97-114.

BRITTO, Paulo Henriques. Tradução e ilusão. Estudos avançados, São Paulo, v. 26, n. 76, p. 21-27, 2012.

BRITTO, Paulo Henriques. Para uma avaliação mais objetiva das traduções de poesia. In: KRAUSE, Gustavo Bernardo. As margens da tradução. Rio de Janeiro: FAPERJ/Caetés/UERJ, 2002.

CORREIA DIAS, Fernanda. Para a Fernandinha ler e contar essas histórias da avó, Cecília Meireles, para os seus irmãozinhos. In: MELLO, Ana Maria Lisboa (org.) Cecília Meireles \& Murilo Mendes. Porto Alegre: Uniprom, 2002.

DINIZ, Telma Franco. Either this ou aquilo: traduzindo a poesia infantil de Cecília Meireles para o inglês. 2012. 227 f. Dissertação (Mestrado em Estudos da Tradução PGET) - Universidade Federal de Santa Catarina, Florianópolis, 2012. Disponível em: https://repositorio.ufsc.br/handle/123456789/99368 Acesso em: mar. 2019.

DINIZ, Telma Franco. Tradução de poesia infantil e sua recepção via Pensar Alto em Grupo: "As meninas" e "O menino (azul)", de Cecília Meireles. 2018. Tese (Doutorado em Estudos da Tradução) - Faculdade de Filosofia, Letras e Ciências Humanas, Universidade de São Paulo, São Paulo, 2018. Disponível em: http://www.teses.usp.br/teses/disponiveis/8/8160/tde-07022019-153420/pt-br.php. Acesso em: mar. 2019. 
FRANCA NETO, Alípio Correia. Poesia via tradução. Palestra proferida em mesa redonda da VIII Jornada de Tradução e Terminologia do CITRAT, USP, 2008.

ISER, Wolfgang. O ato da leitura, v. 1. Traduzido por: Johannes Kretschmer. São Paulo: Ed. 34, 1996.

LAJOLO, Marisa. Do mundo da leitura para a leitura do mundo. 3. ed. São Paulo: Ática, 1997.

LATHEY, Gillian. Translating Children's Literature. Translation Practices Explained. Londres e Nova York: Routledge, 2016.

MEIRELES, Cecília. Ou isto ou aquilo. Ilustrações de Odilon Moraes. 7. ed. São Paulo: Global, 2012.

MEIRELES, Cecília. Problemas da literatura infantil. 4. ed. Rio de Janeiro: Nova Fronteira, 1984.

REDDY, Michael. The conduit metaphor - a case of frame conflict in our language about language. In: ORTONY, Andrew (ed.) Metaphor and thought. Cambridge: Cambridge University Press, 1979. p. 284-324.

ZANOTTO, Mara Sophia. A construção de uma prática de letramento para o ensino e 126 pesquisa de leitura da "metáfora" de textos literários. In: LIMA, Aldo (org.) A propósito da metáfora. Recife: Editora UFPE, 2014.

\footnotetext{
* Telma Franco DINIZ - Doutora em Estudos da Tradução (2018) pela Universidade de São Paulo. Mestre em Estudos da Tradução (2012) pela Universidade Federal de Santa Catarina. Mestre em Engenharia de Alimentos (1991) pela Universidade de São Paulo. Especialista em Tradução Literária (2005) pela Universidade São Paulo. Graduada em Engenharia Química (1983) pela Universidade Federal de Uberlândia. São Paulo, São Paulo, Brasil. Currículo acadêmico: http://lattes.cnpq.br/4763258519762784

ORCID: https://orcid.org/0000-0002-6282-2128

E-mail: telmafranco@hotmail.com
} 